\title{
Resource partitioning among early colonizing Siganus luridus and native herbivorous fish in the Mediterranean: an integrated study based on gut-content analysis and stable isotope signatures
}

\author{
Ernesto Azzurro*§, Emanuela Fanelli†, Edoardo Mostarda*, Marcello Catra ${ }^{\ddagger}$ and Franco Andaloro ${ }^{\varsigma}$ \\ *ICRAM, Central Institute for Marine Research, Laboratory of Milazzo, Via dei Mille 44, 98057 Milazzo (ME), Italy. \\ IAMC-CNR, Marine Ecology Laboratory, Via G. Da Verrazzano 17, 91014 Castellammare del Golfo (TP), Italy. \\ *Università di Catania, Istituto Botanico e Orto Botanico, Via A. Longo 19, 95125 Catania, Italy. SICRAM, \\ STS of Palermo, Via E. Amari 124, 90134, Italy. ${ }^{\S}$ Corresponding author, e-mail: eazzurr@tin.it
}

\begin{abstract}
The present study attempts to give timely information on the resource partitioning between the lessepsian migrant Siganus luridus and two ecological native analogues, Sarpa salpa and Sparisoma cretense. Sampling was carried out in concomitance with the first record of Siganus luridus in Linosa and fish were caught simultaneously, allowing direct comparison of diets. Gut-contents analyses provided a snapshot of the feeding habits of the three species: Siganus luridus fed on 34 taxa of benthic algae (mostly represented by Dictyota dichotoma) and a total of 27 taxa was identified in the stomach of Sarpa salpa, with the predominance of Sargassum vulgare. For the first time, a detailed picture of Sparisoma cretense diet was given ( $\mathrm{N}=22$ taxa of identified algae) albeit, due to the high percentage of digested food, this species was excluded from gut-content comparisons. A certain resource partitioning between Siganus luridus and Sarpa salpa was resolved on the basis of trophic indices and multivariate analyses, these latter also highlighting a more dispersed diet for Siganus luridus with respect to Sarpa salpa. Isotopic signatures were important towards defining the trophic level of the three species and particularly of Sparisoma cretense, whose gut-contents analysis was only partially informative. The values of $\delta^{15} \mathrm{~N}$ confirmed a strictly vegetal diet for Siganus luridus and Sparisoma cretense while Sarpa salpa was significantly more enriched. According to $\delta^{13} \mathrm{C}$, observed values matched the predicted ones for Siganus luridus and Sarpa salpa while both species presented less enriched $\delta^{15} \mathrm{~N}$ values than expected.
\end{abstract}

\section{INTRODUCTION}

The ongoing spread of lessepsian species in the Mediterranean, i.e. migrants from the Red Sea across the Suez Canal, is a matter of growing concern, with new evidence indicating their western expansion across the central sectors of the basin (Azzurro, 2006). Entering into the Mediterranean through the Suez Canal, these invaders have generated remarkable changes in the native communities, especially in the eastern sectors of the basin (Golani, 1998), so that specific studies are highly required. Actually, one of the major constraints in addressing ecological questions is the lack of information from the period prior to invasion (Golani, 1998) or even during the early stages of invasion, when the interaction between exotic and native species are supposed to be negligible. Such information would provide critical power towards assessing the importance of invading events and timely insight as to how to manage the same, but often scientific actions are not undertaken until impact becomes detectable.

Recently, the finding of a newly settled population of the dusky spinefoot Siganus luridus (Rüppel, 1829) (rabbitfish, Siganidae) at the Italian island of Linosa (Azzurro \& Andaloro, 2004) provided a valuable opportunity to study the lessepsian phenomenon (Azzurro, 2006). Siganus luridus belongs to the family of rabbitfish (Siganidae), a group of herbivorous species inhabiting the Indo-West Pacific). Together with its congeneric Siganus rivulatus Forsskål, 1775, S. luridus has a story of successful invasion in the Mediterranean and represents one of the prevailing invaders in the eastern basin (Golani, 1998). In the last two decades, the feeding habits of the dusky spinefoot have been widely studied in the Levantine Sea (e.g. Bariche, 2006 and references therein included) but no information is available from the central Mediterranean.

According to the available literature, only two native fish species are assumed to have feeding analogies with siganids, e.g. Sarpa salpa (Linnaeus, 1758) and Sparisoma cretense (Linnaeus, 1758). Some authors (Bariche et al., 2004) suspected a competitive superiority of Siganidae (particularly Siganus rivulatus) vs Sarpa salpa and others (e.g. Lundberg et al., 2004) claimed that rabbitfish out-competed it but, surprisingly, comparative studies are missing. Moreover, Bariche et al. (2004) hypothesized that the maintenance of the Sparisoma cretense population in the Lebanese coasts may be due to unexamined ecological differences with rabbitfishes, such as in feeding behaviour. In fact, very little information is available on the diet of S. cretense (Petrakis \& Papaconstantinou, 1990).

The recent incoming of Siganus luridus in the island of Linosa adds a new potential link to the use of local trophic resources and stimulates research on the nature of 


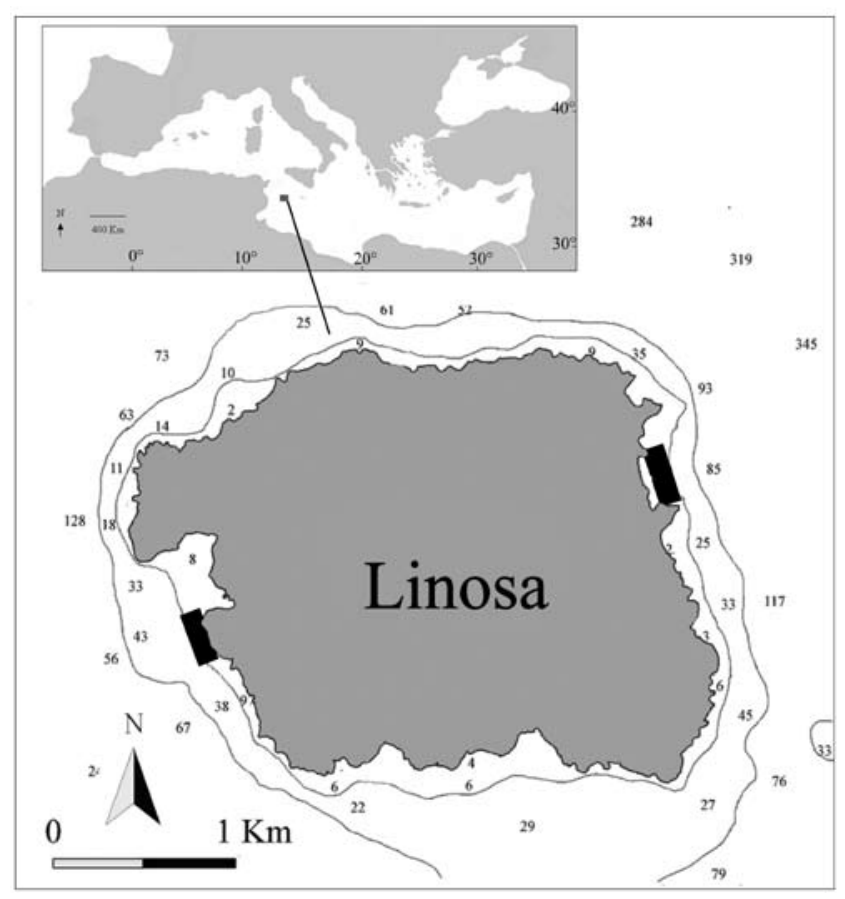

Figure 1. Map showing the study area (Linosa Island) and the sites of fish collection (black rectangles).

competitive interactions between this lessepsian migrant and its native ecological analogues (sensu Herbold \& Moyle, 1986). Gut-contents analysis is a traditional tool with which to address this objective but often temporal and spatial variation is ignored and caution is required when drawing conclusions (Pinnegar \& Polunin, 2000). On the other hand, stable isotope analyses (mainly the ${ }^{13} \mathrm{C}$ and ${ }^{15} \mathrm{~N}$ ) yield information on what is actually assimilated and provide relatively long-term and time-integrated measurements of feeding preferences, because they are less subject to temporal bias (Pinnegar \& Polunin, 2000; Vizzini et al., 2002). Animals typically possess more of the heavier isotopes ${ }^{13} \mathrm{C}$ or ${ }^{15} \mathrm{~N}$ than their food and an enrichment occurs with each trophic level in food webs/chains, providing the basis for analysis of complex food chain interrelationships, trophic pathways and food webs.

The goal of the present study was to provide timely information about the diet of Siganus luridus in its newly colonized habitat and the native herbivorous fish Sarpa salpa and Sparisoma cretense. To address this aim we attempted to: (1) characterize the feeding habits of the three sympatric species in the study area; (2) compare their diets; and (3) determine the ${ }^{13} \mathrm{C}$ and ${ }^{15} \mathrm{~N}$ composition of these fish and their main food items.

\section{MATERIALS AND METHODS}

\section{Study site}

Linosa $\left(35^{\circ} 51^{\prime} \mathrm{N} 12^{\circ} 51^{\prime} \mathrm{E}\right)$ (Figure 1) is a small volcanic island $\left(5.4 \mathrm{~km}^{2}\right.$ wide) originating in the Quaternary period. It belongs to the Pelagean archipelago, located in the middle of the Sicily Strait at the western limit of the so called 'lessepsian province'. The coastline has a limited extension $(11 \mathrm{~km})$ and the surrounding bottoms reach rapidly depths of $300 \mathrm{~m}$. Due to a reduced anthropogenic pressure, the island is largely undisturbed and recently (in October 2002) it was declared a Marine Protected Area, even though effective protection measures were still not in force during the study period. Along the Linosa infra-littoral rocky bottoms, Sarpa salpa and Sparisoma cretense occur with high abundances, representing two of the prevailing fish species, whilst the recently settled Siganus luridus, scattered in small groups of individuals, is rather uncommon in the island (Azzurro et al., 2007).

\section{Sample collection and processing}

Sarpa salpa $(\mathrm{N}=18)$, Sparisoma cretense $(\mathrm{N}=36)$ and early settled Siganus luridus $(\mathrm{N}=40)$ were caught through July-August 2003 during daylight hours (0800-1800 h). Total length (TL) was $13.5-27.5 \mathrm{~cm}, 12.8-25.3 \mathrm{~cm}$ and $13.6-24.5 \mathrm{~cm}$, respectively. All fish were caught at two different locations along the western and eastern infra-littoral rocky bottoms (depth range 1-8 m) of Linosa (Figure 1). The $S$. luridus specimens represented the first record of rabbitfish in the Pelagean archipelago (Azzurro \& Andaloro, 2004). The sampling technique, by spear-fishing, allowed for the capture of fish simultaneously from the same sites and prevented the rapid digestion of food. Immediately after capture, length and weight were determined and digestive tracts were extracted and preserved in $6 \%$ buffered formalin.

For the stable isotope analyses, six specimens of each fish species Siganus luridus, Sparisoma cretense and Sarpa salpa were immediately frozen at $-20^{\circ} \mathrm{C}$. Mean size of samples was $15.8 \pm 0.9 \mathrm{~cm}$ TL, $18.3 \pm 2.3 \mathrm{~cm}$ TL, $17.3 \pm 2.6 \mathrm{~cm}$ TL for Siganus luridus, Sparisoma cretense and Sarpa salpa, respectively. At the same time and in the same sites of study, dominant macrophytae were collected and immediately frozen at -20 $\mathrm{C}^{\circ}$ for isotope analyses.

\section{Gut-content analysis}

Digestive tracts were opened in the laboratory, and contents were blotted dry with absorbent paper. Total wet weight was recorded to the nearest $0.001 \mathrm{~g}$ and an index of stomach fullness was calculated as the ratio between the total weight of stomach content and total fish weight. Subsequently all food items were identified to the lowest possible taxon under a dissecting microscope. Each taxon was then separated, blotted dry and weighted. In order to measure sample size sufficiency, the cumulative number of food items against the cumulative number of gut analysed was plotted (Ferry \& Cailliet, 1996). The logistic and linear regressions were calculated and the respective goodness of fit coefficients $\mathrm{R}^{2}$ were compared. The sample size was considered sufficient when $\mathrm{R}^{2}$ for the logistic curve was higher than the $\mathrm{R}^{2}$ for the linear relation (Castriota et al., 2005). The contribution of each food item to the diet was expressed as percentage frequency of occurrence $(\% \mathrm{~F})$ and percentage by weight $(\% \mathrm{~W})$. The most important food items were determined using the index of relative importance (IRI) modified according to the requirements of the present study as IRI $=\% \mathrm{~W} * \% \mathrm{~F}$. This index was then expressed on a per cent basis as: $\%$ IRI=100*IRI/ $/ 2$ IRI $_{i}$.

The Schoener index of overlap was used to assess the diet similarity of the two species. The mean per cent wet weight was calculated for each food item. This index was then 
Table 1. Results of the sample size sufficiency analysis for the total number of Siganus luridus, Sarpa salpa and Sparisoma cretense examined guts.

\begin{tabular}{|c|c|c|c|c|c|c|}
\hline & \multicolumn{3}{|c|}{ Logistic regression } & \multicolumn{3}{|c|}{ Linear regression } \\
\hline & $\mathrm{R}^{2}$ & $\mathrm{~F}$ & $P$ & $\mathrm{R}^{2}$ & $\mathrm{~F}$ & $P$ \\
\hline Siganus luridus & 0.892 & $\mathrm{~F}_{1,36}=296.12$ & $<0.001$ & 0.701 & $\mathrm{~F}_{1,36}=84,51$ & $<0.001$ \\
\hline Sarpa salpa & 0.942 & $\mathrm{~F}_{1,16}=259.06$ & $<0.001$ & 0.874 & $\mathrm{~F}_{1,16}=111.25$ & $<0.001$ \\
\hline Sparisoma cretense & 0.690 & $\mathrm{~F}_{1,34}=76.15$ & $<0.001$ & 0.548 & $\mathrm{~F}_{1,34}=41.21$ & $<0.001$ \\
\hline
\end{tabular}

calculated as follows:

$\alpha=1-0.5\left(\sum\left|p_{i j}-p_{i k}\right|\right)$

where $p_{i j}$ is the proportion of food item used by species $j$, and $\mathrm{p}_{\mathrm{ik}}$ is the proportion of food item $\mathrm{i}$ used by species $\mathrm{k}$. $\alpha$ varies between 0 and 1.0, representing no to complete food overlap, respectively. The degree of overlap between two species diets is considered significant when the index is greater than 0.60 .

The diet breadth was calculated using Levin's standardized index:

$$
B_{i}=\frac{1}{n-1}\left(\frac{1}{\sum p_{x i}^{2}}-1\right)
$$

where $B_{i}=$ Levin's standardized index for predator $i, p_{\mathrm{xi}}=$ proportion of diet of predator $i$ that is made up of prey $x$, $n=$ number of prey categories. This index ranges from 0 to 1; low values indicate diets dominated by few prey items (specialist predators); higher values indicate generalist diets.

\section{Isotope analyses}

Isotopic analyses were performed on muscle tissue samples (portions of white muscle close to dorsal fin) of the three fish species and nine macrophytae (chosen on the basis of their relevance in gut-content analysis). According to each fish species, we analysed six individuals of the same size (ANOVA $P>0.05)$. For each species of macrophytae, we analysed two samples taken from a composite sample of specimens.

Samples of both fish and macrophytae were dried to constant weight at $60^{\circ} \mathrm{C}$ in a fan-assisted oven before being ground to a fine powder with a mortar and pestle.

Using continuous flow, the samples were introduced into a Finnigan Delta plus XP isotope ratio mass spectrometer for isotopic analysis. $\delta^{13} \mathrm{C}$ and $\delta^{15} \mathrm{~N}$ values were obtained in parts per thousand $(\%)$ relative to Vienna Pee Dee Belemnite (vPDB) and atmospheric $\mathrm{N}_{2}$ standards, respectively, according to the following formula:

$\delta^{13} \mathrm{C}$ or $\delta^{15} \mathrm{~N}=[($ Rsample $/$ Rstandard $)-1] \times 10^{3}$

where $\mathrm{R}={ }^{13} \mathrm{C} /{ }^{12} \mathrm{C}$ or ${ }^{15} \mathrm{~N} /{ }^{14} \mathrm{~N}$.

For each species, the nitrogen and carbon isotope signatures predicted from their diets were calculated using a weighted-average equation of the following form (shown for $\left.\delta^{15} \mathrm{~N}\right)$ :

$$
\sum_{i=1}^{k} \delta^{15} \mathrm{~N} \frac{b_{i}}{b t}+f \quad \text { and } \quad b t=\sum_{i=1}^{k} b_{i}
$$

where $\delta^{15} \mathrm{~N}$ is the nitrogen isotope signature of the $i$ th prey item, bi/bt is the proportion of diet biomass observed for that prey item, and $f$ is the trophic fractionation coefficient which was chosen of $3.4 \%$ for $\delta^{15} \mathrm{~N}$ and $1 \%$ for $\delta^{13} \mathrm{C}$.

\section{Statistical analyses}

Multivariate analyses of gut-contents data were performed only for Siganus luridus and Sarpa salpa while Sparisoma cretense was excluded, due to the high amount (92-95\%) of digested unidentifiable material in the gut contents. Firstly, analysis of similarities (ANOSIM) was done in order to test for possible differences between the diet of each species sample belonging to the two sampling locations. Principal component analysis (PCO) was performed on Bray-Curtis distance based on 4th root transformed and standardized biomass data. Based on the null-hypothesis that no differences exist among species diet, a permutational multivariate analysis of variance (PERMANOVA) design was created on one factor to detect significant differences between Siganus luridus and Sarpa salpa diets. A PERMDISP test (Anderson, 2006), a distance-based test for homogeneity of multivariate dispersions, was then performed in order to compare the multivariate dispersions among species. The similarity percentage analysis (SIMPER) procedure was used to identify those species that characterized each diet and those responsible for discriminating between diets. Uncommon species that were seldom present or exhibited low abundance levels were not included in the data matrix. Multivariate analyses were performed by means of the software PRIMER 6 plus PERMANOVA (Clarke \& Warwick, 1994; Anderson, 2006).

One-way ANOVA was used to compare isotopic signatures within all fish species. The Tukey HSD test was applied a posteriori to locate the source of any difference.

\section{RESULTS}

\section{Gut-contents analysis}

All of Siganus luridus, Sarpa salpa and Sparisoma cretense digestive tracts examined were full and the index of fullness exhibited high values $(8.26 \pm 2.18,7.93 \pm 1.87,6.83 \pm 3.77$, respectively). The cumulative prey types curve resulted as fitting better with a logistic curve than with a linear relation for Siganus luridus, Sarpa salpa and Sparisoma cretense when $100 \%$ of the guts examined was considered; then sample size was considered sufficient to describe the diet of each species (Table 1).

The analysis of Siganus luridus gut contents led to the identification of 34 taxa of benthic algae and one sea grass 
Table 2. Overall food items of Siganus luridus, Sarpa salpa and Sparisoma cretense in Linosa Island.

\begin{tabular}{|c|c|c|c|c|c|c|c|c|c|}
\hline \multirow[b]{2}{*}{ Food items } & \multicolumn{3}{|c|}{ Siganus luridus } & \multicolumn{3}{|c|}{ Sarpa salpa } & \multicolumn{3}{|c|}{ Sparisoma cretense } \\
\hline & $\% \mathrm{~F}$ & $\% \mathrm{~W}$ & $\%$ IRI & $\% \mathrm{~F}$ & $\% \mathrm{~W}$ & $\%$ IRI & $\% \mathrm{~F}$ & $\% \mathrm{~W}$ & \%IRI \\
\hline Chlorophyta & 63.16 & 3.96 & 2.58 & 38.89 & 3.23 & 1.63 & 19.44 & 0.13 & 0.38 \\
\hline Anadyomene stellata & 28.95 & 0.84 & 0.32 & 5.56 & 0.01 & $<0.01$ & 2.78 & 0.02 & $<0.01$ \\
\hline Bryopsis sp. & 7.89 & 0.01 & $<0.01$ & 5.56 & $<0.01$ & $<0.01$ & - & - & - \\
\hline Caulerpa racemosa & 28.95 & 1.55 & 0.58 & - & - & - & - & - & - \\
\hline Cladophora sp. & 34.21 & 1.50 & 0.67 & 27.78 & 0.07 & 0.03 & 8.33 & 0.05 & $<0.01$ \\
\hline Dasycladus vermicularis & 7.89 & 0.02 & $<0.01$ & - & - & - & - & - & - \\
\hline Microdictyon tenuius & 2.63 & 0.05 & $<0.01$ & - & - & - & - & - & - \\
\hline Ulva sp. & - & - & - & 5.56 & 3.15 & 0.28 & - & - & - \\
\hline Flabellia petiolata & - & - & - & - & - & - & 2.78 & 0.02 & $<0.01$ \\
\hline Valonia sp. & - & - & - & - & - & - & 5.56 & 0.05 & $<0.01$ \\
\hline Heterokontophyta & 100.00 & 89.20 & 92.26 & 100.00 & 66.59 & 86.53 & 100 & 3.69 & 53.96 \\
\hline Asperococcus sp. & - & - & - & 5.56 & 0.26 & 0.02 & - & - & - \\
\hline Cystoseira humilis & 13.16 & 0.19 & 0.03 & 55.56 & 5.42 & 4.85 & 5.56 & 0.12 & 0.01 \\
\hline Cystoseira sp. & 26.32 & 12.43 & 4.25 & 50.00 & 0.66 & 0.53 & 19.44 & 0.28 & 0.06 \\
\hline Dictyopteris polypodioides & 28.95 & 0.07 & 0.03 & 66.67 & 3.14 & 3.37 & - & - & - \\
\hline Dictyota dichotoma & 34.21 & 2.41 & 1.07 & 16.67 & 0.43 & 0.11 & - & - & - \\
\hline Dictyota dichotoma var. intricata & 47.37 & 1.86 & 1.15 & 5.56 & 1.05 & 0.09 & - & - & - \\
\hline Dictyota sp. & 97.37 & 64.31 & 81.47 & 77.78 & 16.96 & 21.23 & 16.67 & 0.14 & 0.02 \\
\hline Halopteris filicina & 97.36 & 4.16 & 5.27 & 100 & 3.76 & 6.05 & 75 & 1.34 & 0.55 \\
\hline Lobophora variegata & 15.79 & 0.29 & 0.06 & 5.56 & $<0.01$ & $<0.01$ & - & - & - \\
\hline Padina pavonica & 42.11 & 0.78 & 0.42 & 83.33 & 3.37 & 4.52 & - & - & - \\
\hline Sargassum sp. & 13.16 & 0.07 & 0.01 & 5.56 & 5.30 & 0.47 & - & - & - \\
\hline Sargassum vulgare & 36.84 & 1.31 & 0.63 & 83.33 & 25.02 & 33.57 & 2.78 & 0.05 & $<0.01$ \\
\hline Sphacelaria cirrosa & 10.53 & 0.05 & 0.01 & - & - & - & 11.11 & 0.16 & 0.02 \\
\hline Sphacelaria sp. & 55.26 & 0.71 & 0.51 & 61.11 & 0.85 & 0.84 & 66.67 & 0.95 & 0.66 \\
\hline Sphacelaria tribuloides & 7.89 & 0.02 & $<0.01$ & 11.11 & 0.09 & 0.02 & - & - & - \\
\hline Stypocaulon scoparium & 44.74 & 0.54 & 0.31 & 33.33 & 0.28 & 0.15 & 55.56 & 0.65 & 0.38 \\
\hline Rhodophyta & 94.74 & 5.15 & 5.05 & 77.78 & 5.93 & 5.99 & 91.67 & 2.06 & 27.58 \\
\hline Acrosorium ciliolatum & 26.31 & 1.88 & 0.64 & 11.11 & 0.11 & 0.02 & - & - & - \\
\hline Alsidium sp. & 21.05 & 0.07 & 0.02 & 5.56 & 0.03 & $<0.01$ & - & - & - \\
\hline Botryocladia sp. & 39.47 & 0.27 & 0.14 & 16.67 & 0.03 & 0.01 & 8.33 & 0.06 & $<0.01$ \\
\hline Corallophila cinnabarina & 21.05 & 0.18 & 0.05 & - & - & - & - & - & - \\
\hline Dasya sp. & 2.63 & 0.05 & $<0.01$ & - & - & - & - & - & - \\
\hline Eupogodon planus & 13.16 & 0.07 & 0.01 & 5.56 & $<0.01$ & $<0.01$ & - & - & - \\
\hline Ceramium sp. & - & - & - & - & - & - & 5.56 & 0.02 & $<0.01$ \\
\hline Gelidium sp. & 13.16 & 0.07 & 0.01 & - & - & - & 25.00 & 0.12 & 0.03 \\
\hline Hypnea sp. & - & - & - & 16.67 & 3.11 & 0.84 & - & - & - \\
\hline Hypoglossum hypoglossoides & 10.53 & 0.24 & 0.03 & - & - & - & 2.78 & 0.01 & $<0.01$ \\
\hline Haliptilon virgatum & - & - & - & - & - & - & 47.22 & 0.81 & 0.40 \\
\hline Fania rubens & - & - & - & - & - & - & 27.78 & 0.58 & 0.17 \\
\hline Laurencia sp. & 10.53 & 0.01 & $<0.01$ & 33.33 & 0.78 & 0.42 & 13.89 & 0.04 & 0.01 \\
\hline Monosporus pedicellatus & 2.63 & 0.04 & $<0.01$ & - & - & - & - & - & - \\
\hline Nitophyllum sp. & - & - & - & 5.56 & 1.03 & 0.09 & - & - & - \\
\hline Peyssonnelia sp. & 60.53 & 2.23 & 1.76 & 55.56 & 0.84 & 0.75 & 13.89 & 0.16 & 0.02 \\
\hline Polysiphonia sp. & 5.26 & 0.04 & $<0.01$ & - & - & - & 38.89 & 0.19 & 0.08 \\
\hline Polysiphonia opaca & 2.63 & $<0.01$ & $<0.01$ & - & - & - & 2.78 & 0.08 & $<0.01$ \\
\hline Spermatophyta & 57.89 & 0.18 & 0.11 & 38.89 & 11.57 & 5.85 & 80.56 & 1.54 & 18.08 \\
\hline Posidonia oceanica & 57.89 & 0.18 & 0.14 & 38.89 & 11.57 & 7.25 & 80.56 & 1.54 & 1.29 \\
\hline \multicolumn{10}{|l|}{ Other items } \\
\hline Unidentified algae & 34.21 & 0.19 & 0.08 & 16.67 & 1.07 & 0.29 & 2.78 & 0.02 & $<0.01$ \\
\hline Digested materials & 23.68 & 0.81 & 0.15 & 88.89 & 11.47 & 14.14 & 100.00 & 92.51 & 96.30 \\
\hline Inorganic materials & 21.05 & 0.39 & 0.11 & 11.11 & 0.09 & 0.02 & 2.78 & 0.05 & $<0.01$ \\
\hline Amphipods & 21.05 & 0.06 & 0.02 & 22.22 & 0.02 & 0.01 & - & - & - \\
\hline Foraminiferans & 50.00 & 0.07 & 0.05 & 66.67 & 0.03 & 0.03 & 2.78 & $<0.01$ & $<0.01$ \\
\hline
\end{tabular}

$\% \mathrm{~F}$, occurrence frequency of prey; \%W, percentage by weight; \%IRI, index of relative importance. 


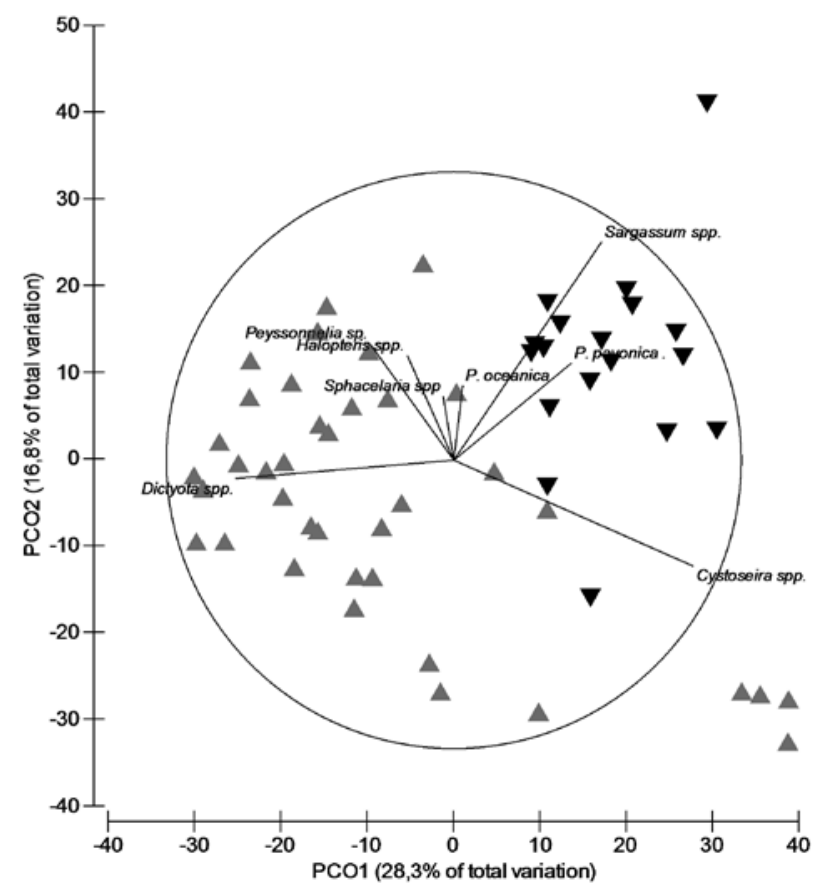

Figure 2. Principal component analysis ordination plot of 4th root transformed gut-contents data for Siganus luridus (black triangles) and Sarpa salpa (grey triangles) specimens. Overlay variables were the most typifying species as evidenced by SIMPER analysis.

(Posidonia oceanica) (Table 2). Brown algae were, according to all indices, the most important food item $(\% \mathrm{~F}=100$, \%W=89.20, \%IRI=92.26). Among them, Dictyota sp. was the dominant taxon according to all indices. Cystoseira sp. was the second most represented food item with reference to $\% \mathrm{~W}$ and \%IRI. According to \%W, other important species were Halopteris filicina, Dictyota dichotoma and Peyssonnelia sp. Several species were recorded frequently but were of minor importance according to $\% \mathrm{~W}$ and \%IRI. The introduced green alga Caulerpa racemosa was exclusively present. Foraminiferans were found frequently even if their contribution in terms of biomass was low. Amphipods were recorded occasionally. Siganus luridus showed very low values of niche width $(\mathrm{B}=0.027$ ).

In the gut-contents of Sarpa salpa, 27 taxa of benthic algae plus $P$. oceanica were identified (Table 2). Overall, brown algae constituted the dominant group according to $\% \mathrm{~F}$ (100\%), \%W (66.59\%) and \%IRI (86.53\%). Among them, the most represented species was Sargassum vulgare followed by Dictyota sp. P. oceanica, even if not very frequent, showed a good contribution with reference to $\% \mathrm{~W}$ and $\%$ IRI. Other relevant species were Cystoseira sp., Padina pavonica, Dictyopteris polypodioides and $H$. filicina. Sarpa salpa showed low values of niche width $(\mathrm{B}=0.212)$.

The diet of Sparisoma cretense was characterized by the substantial incidence of highly digested materials $(\% \mathrm{~W}=92.51$, \%IRI=96.30) while, among the remaining percentage of identifiable food items, 22 taxa of algae and Posidonia oceanica, were identified (Table 2). According to \%IRI, brown algae were the predominant food item, followed by red algae and $P$. oceanica. The latter was the most frequent and important species. Other food items such as Sphacelaria sp., Stypocaulon scoparium, Haliptilon virgatum and Halopteris filicina were frequent but showed low values in terms of $\% \mathrm{~W}$ and $\%$ IRI.

Since no differences among samples from different locations were found for both Siganus luridus and Sarpa salpa (ANOSIM R $=0.003, \mathrm{R}=0.004$ respectively and $P>0.05$ ), the analyses were performed on the whole sample, excluding the factor 'location'. Schoener's index was 0.262, indicating a very low overlap between Siganus luridus and Sarpa salpa diets.

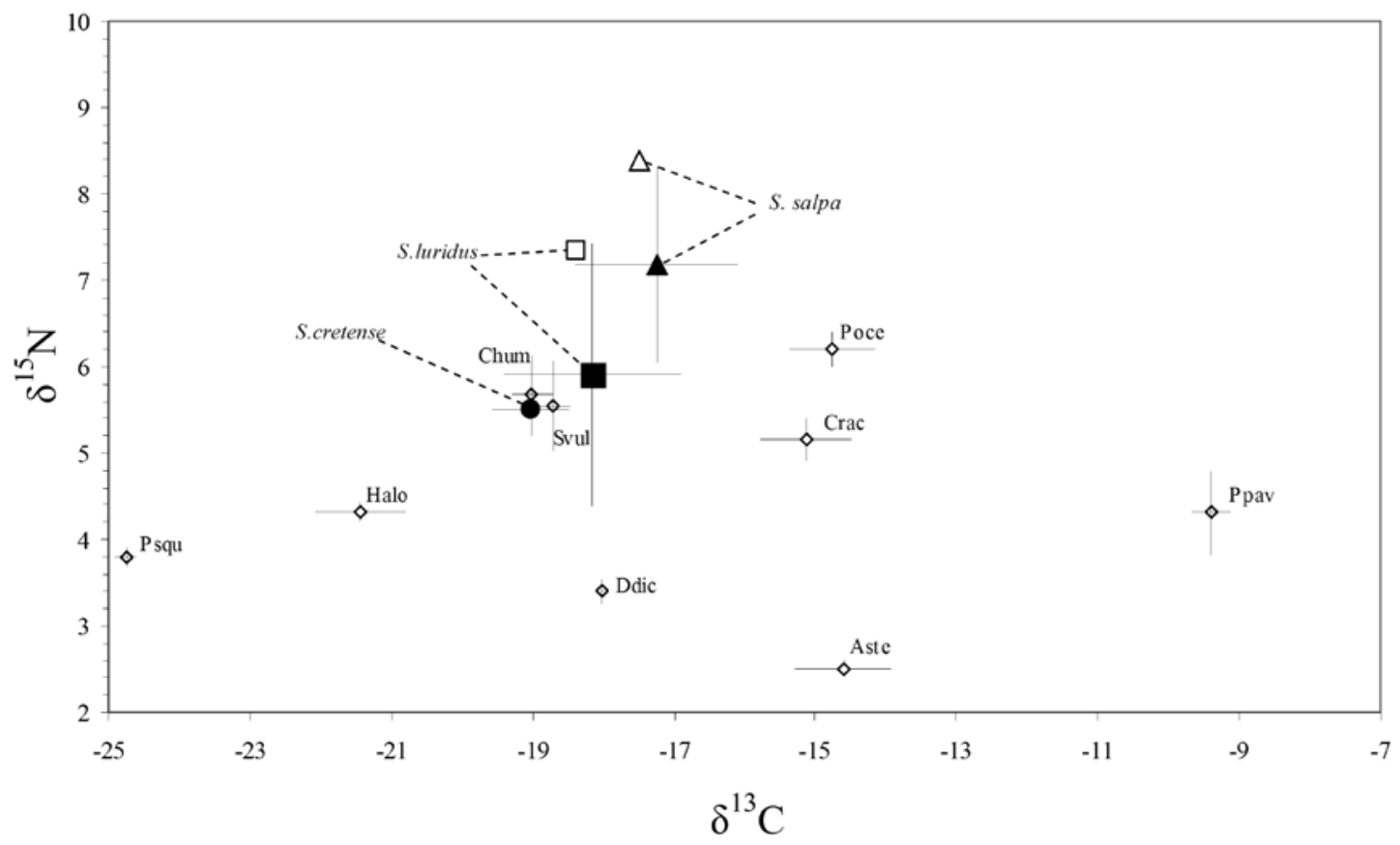

Figure 3. Plot of the $\delta^{13} \mathrm{C}$ vs $\delta^{15} \mathrm{~N}$ values (mean $\% \pm \mathrm{SD}$ ) for food items and fish. The empty triangle and square represent predicted values by means of eqn 4. Svul, Sargassum vulgare; Aste, Anadyomene stellata; Chum, Cystoseira humilis; Psqu, Peyssonellia squamaria; Halo, Halopteris sp.; Ddic, Dictyota dichotoma; Ppav, Padina pavonica; Crac, Caulerpa racemosa; Poce, Posidonia oceanica. 
The PCO analysis (Figure 2) highlighted a clear separation among species diets with the first two axes explaining $45.1 \%$ of total variance. The PERMANOVA provided evidence for statistically significant differences in species diets $\left(\mathrm{F}_{1,55}=10.58 ; P=0.001\right)$. The PERMDISP procedure also showed a significantly higher dispersion $(\mathrm{F}=6.1 ; P=0.03)$ for Siganus luridus with respect to Sarpa salpa (34.7 and 27.4 respectively).

The SIMPER analysis showed a higher value of intraspecific similarity for Sarpa salpa (59.2\%) than for Siganus luridus (50.6\%). Dictyota spp. and Halopteris spp. accounted for $47.7 \%$ and $18.9 \%$ of the average similarity in S. luridus, while Dictyota spp. (22.4\%), Sargassum spp. (20.9\%), Cystoseira spp. (14.6\%) and Halopteris spp. (14.5\%) were the most typifying species in Sarpa salpa. Finally, Dictyota spp., Sargassum spp. and Cystoseira spp. were the food items that contributed the most to the average dissimilarity between these two species.

\section{Isotope analysis}

The $\delta^{15} \mathrm{~N}$ isotopic value of Siganus luridus was $5.9 \% \pm 1.1$, of Sarpa salpa $7.2 \% \pm \pm 1.5$ and of Sparisoma cretense $5.5 \% \pm \pm 0.2$. ANOVA tests showed significant differences both in $\delta^{15} \mathrm{~N}$ $\left(\mathrm{F}_{1,15}=3.8 ; P<0.05\right)$ and $\delta^{13} \mathrm{C}\left(\mathrm{F}_{1,15}=4.5 ; P<0.05\right)$ values among fish. According to the post-hoc Tukey HSD test, the $\delta^{15} \mathrm{~N}$ values were significantly higher in Sarpa salpa than Sparisoma cretense and the $\delta^{13} \mathrm{C}$ values more depleted in $S$. cretense ($19.0 \% \pm \pm 0.5)$ than in Sarpa salpa $(-17.2 \% \pm \pm 1.2)(P<0.05)$.

There was a very wide variation in the $\delta^{13} \mathrm{C}$ and $\delta^{15} \mathrm{~N}$ of the studied food items, with Padina pavonica being particularly enriched in $\delta^{15} \mathrm{~N}(-9.1 \%$ o $)$ and Peyssonellia squamaria particularly depleted $\left(-24.7 \%\right.$ ). According to $\delta^{15} \mathrm{~N}$, the highest values were recorded for Posidonia oceanica, Cystoseira humilis and Sargassum vulgare, while the lowest were recorded for D. dichotoma and Anadyomene stellata (Figure 3).

The $\delta^{15} \mathrm{~N}$ values of Siganus luridus and Sarpa salpa were less enriched than expected on the basis of consumed food items (Figure 3). In fact, predicted values (through eqn 4) for $\delta^{15} \mathrm{~N}$ signatures were respectively $1.4 \%$ and $1.3 \%$ more enriched than the mean observed values. Conversely, the predicted $\delta^{13} \mathrm{C}$ signatures matched with the observed ones.

\section{DISCUSSION}

Our study provides timely information on the feeding habits of Linosa herbivorous fish species, at a stage where slightly invasive versus native species interaction is supposed to act. Results verify the capacity of the lessepsian rabbitfish Siganus luridus to adapt to local trophic resources and confirmed the success of these first colonizers. Gut-content analysis showed clear differences between the feeding preferences of $S$. luridus and Sarpa salpa and a good resource partitioning among them. Clearly, these results are limited to the period of study (summer) and seasonal variations have been not taken into account. Moreover, we do not know whether changes in the herbivorous abundance (a possible expansion of rabbitfish) and the subsequent increase of feeding pressure may lead to a lowering of the algal resource. In any case, a weakening of dietary niche-partitioning is expected only if the preferred algae should turn into a limited resource. Given the recent spreading of Siganus luridus across the central Mediterranean, studies on early settled populations assume a certain importance. However, up to date, their limited abundances in the newly colonized areas do not support extensive temporal and spatial samplings which would allow to better define their trophic niche.

\section{Diet of single species}

Plotting the number of food items versus the number of analysed gut-contents, data resulted which were representative of the full array of preys. Notwithstanding the small number of samples, this is not surprising. In fact, the study of herbivore species diet has some advantage presenting much less intra-specific variability, with respect to carnivores or omnivores (Stergiou \& Karpouzi, 2002).

The stomach fullness was high in $S$. luridus, even if these specimens were captured during the reproductive period (Azzurro, 2006), when the feeding should be at its minimum (Stergiou, 1988). Actually, Stergiou (1988) provided very low values of the fullness index in comparison with our study (values around 1 against $8.26 \pm 2.18$ ) which were possibly due to the different sampling methods. With 34 identified taxa of benthic algae and one sea grass, the qualitative screening of $S$. luridus diet resulted as being considerably broad compared with previous studies (see Bariche, 2006) testifying to the wideness of the $S$. luridus trophic spectrum in its newly colonized area, and a wide availability of algal resources. According to Serio et al. (2006), 233 species characterize the phytobenthos of Linosa Island, accounting for numerous tropical affinity taxa consumed by $S$. luridus. Particularly abundant and rich species are brown algae, which are the favourite food items for $S$. luridus, and this abundance could have facilitated the establishment of the dusky rabbitfish across the central Mediterranean (Lundberg \& Golani, 1995).

Gut-content analysis showed some similarities between the early settled $S$. luridus and the eastern Mediterranean populations (Bariche, 2006). In Linosa, Dyctiota spp. were the main and favourite food items followed by Cystoseira sp. Instead Sargassum sp. and calcareous algae, which are widely distributed in this area (Serio et al., 2006) were of minor importance in Siganus luridus diet. Particularly noteworthy was Caulerpa racemosa, an introduced Red Sea macroalga which occurs along Linosa's shallower waters in the form of occasional patchy mats (E. Azzurro, personal observation). The spread of C. racemosa across the Mediterranean coastal habitats is a matter of growing concern and its significance for $S$. luridus diet represents an interesting example of the way in which some invading species interact with other not-native ones, possibly facilitating their establishment. Previously, C. racemosa was found for S. luridus caught in Cyprus (Lundberg et al., 1999) and some caution has been recommended regarding the consumption of siganids which ingested this toxic alga (Bariche, 2006).

For Sarpa salpa, the most represented food item was Sargassum vulgare followed by Dictyota sp. The sea grass Posidonia oceanica showed a good contribution in terms of $\% \mathrm{~W}$ and \%IRI, in accordance with a variety of other studies (Havelange et al., 1997 and references therein included). The green alga Ulva sp. resulted as being exclusive for Sarpa salpa together with Nitophyllum sp. and Hypnea sp.

The feeding habits of Sparisoma cretense are mostly unknown (Petrakis \& Papaconstantinou, 1990) and our results, with 23 
identified taxa of macrophytae, represented the first detailed information about its diet. As well as in other scarids, the identification of food items in $S$. cretense was particularly difficult, the food being highly fragmented by the grinding of pharyngeal teeth and highly digested. Reasonably, the less leathery items (such as tender or filamentous algae) are digested with more facility and could be underestimated by the analysis. The opposite happens to tough macrophytae, such as calcareous algae or sea grass, which are more resistant to digestion.

\section{Siganus luridus vs Sarpa salpa}

The simultaneous capture of fish and their similar sizerange enabled us to perform a direct comparison of diets (Lundberg \& Golani, 1995), at least for the temporal and spatial range considered here. According to the statistical analyses, the two diets were characterized by a low overlap and a high degree of dissimilarity, with Sargassum spp., Cystoseira spp. and Dictyota spp. as the food items that mostly contributed to such differentiation. Notwithstanding the predominance of Dictyota spp. in the gut contents of Siganus luridus, the diet of this species seems to be more dispersed (many other rare food items are grazed) in comparison with Sarpa salpa. It has to be noticed that these habits are expected to vary on a seasonal basis as observed in the eastern Mediterranean, where the dusky spinefoot presented low values of trophic breadth in autumn (October), intermediate values in summer (July) and high values in spring (MarchApril) (Stergiou, 1988).

Assuming that the same algal resources were available for both species (that is reasonable considering that all the individuals were sampled in the same sites), results indicated that the early settled Siganus luridus and the native Sarpa salpa tend to choose their own diet with a good trophic partitioning. Considering the short period of time since colonization and the rarity of Siganus luridus in Linosa (Azzurro et al, 2007), the differences between the diets of these two species cannot be related to some ecological switch. This is instead a common and predictable consequence of competitive interactions within fish communities (Hanson \& Leggett, 1986).

Elton (1958) suggested that 'empty niches', i.e. the existence of ecological space and the lack of competition within some communities, facilitated the establishment of invading species. In recent times, this hypothesis has received much attention, even if some controversy has grown (Herbold \& Moyle, 1986). In many cases, the success of lessepsian species in the Mediterranean has been explained with this assumption (e.g. Golani, 1994) and siganids are thought to be one among the clearest examples of that (Lundberg \& Golani, 1995). Actually other potentially important biological and ecological characters could lie behind the success of the dusky spinefoot and future studies should be aimed at better defining its ecological niche and making specific comparison with native species.

\section{The isotopic signatures}

Isotopic signatures were important towards defining the trophic level of the three species and particularly of Sparisoma cretense, whose gut-contents analysis was only partially informative. Both isotopic signatures assigned Siganus luridus, Sarpa salpa and Sparisoma cretense to the same functional group of herbivores. This information, which is new for Sparisoma cretense, agrees with the review of Stergiou \& Karpouzi (2002), which indicated the rabbitfish (Siganus luridus and Siganus rivulatus) and Sarpa salpa as the fish species with the lowest trophic level in the Mediterranean (TROPH=2.00, mean=2.00, TROPH=2.00-2.50, mean=2.13 respectively). However, the values of $\delta^{15} \mathrm{~N}$ suggested that the diet of Siganus luridus and Sparisoma cretense is based exclusively on vegetal items, while Sarpa salpa was significantly more enriched. The $\delta^{15} \mathrm{~N}$ values of $S$. salpa were similar to those observed by Pinnegar \& Polunin (2000) while both Jennings et al. (1997) and Vizzini et al. (2002) observed $\delta^{15} \mathrm{~N}$ higher values. The highest trophic level of Sarpa salpa could be explained by the presence of food items with a higher $\delta^{15} \mathrm{~N}$ such as some invertebrates, as shown by Jennings et al. (1997) and Pinnegar \& Polunin (2000). According to Verlaque (1985) another possible source of nitrogen may be the faeces of planktivorous fish such as Chromis chromis or Spicara maena consumed by young Sarpa salpa.

The values of $\delta^{15} \mathrm{~N}$ for several macrophytae, were higher in comparison with other Mediterranean areas (Pinnegar \& Polunin, 2000) and comparable to eutrophic habitats (Vizzini et al., 2002). These differences may be due to physiological factors (enzymatic discrimination during photosynthesis) and to a different ability to use different nitrogen sources.

According to the food items, the substantial variation in the isotopic signature for both $\delta^{13} \mathrm{C}$ and $\delta^{15} \mathrm{~N}$ values combined with their high number gave little information on resource partitioning between the species. However, according to $\delta^{13} \mathrm{C}$, observed values matched the predicted ones for Siganus luridus and Sarpa salpa while both species presented less enriched $\delta^{15} \mathrm{~N}$ values than expected (Figure 3). Assuming that food items were assimilated into tissue at the same proportions which were ingested, three explanations could be inferred to explain such bias: (1) the actual $\delta^{15} \mathrm{~N}$ fractionation value could be lower than 3.4\%o; (2) Siganus luridus and Sarpa salpa feed on less enriched food items during the other seasons; and (3) the $\delta^{15} \mathrm{~N}$ values of macroalgae in summer are more enriched in comparison with the rest of the year. Future studies which consider the seasonal variability in the diet of these species and in the $\delta^{15} \mathrm{~N}$ and $\delta^{13} \mathrm{C}$ food sources are required in order to clarify this aspect.

We would like to thank Professor O. Carnevali for assisting this research during the $\mathrm{PhD}$ course, Dr M. Sprovieri and Ms P. Rumolo for their help in isotopes analysis, Dr F. Badalamenti for critical reading of the manuscript, Professor G. Giaccone for assistance in identifying algal species and Ms E. Jablon for reviewing our English.

\section{REFERENCES}

Anderson, M.J., 2006. Distance-based test for homogeneity of multivariate dispersions. Biometrics, 62, 245-253.

Azzurro, E., Pais, A., Consoli, P. \& Andaloro, F., 2007. Evaluating day-night changes in shallow Mediterranean rocky reef fish assemblages by visual census. Marine Biology, 151, 2245-2253.

Azzurro, E., 2006. Cambiamento della diversità ittica in Mediterraneo: casi di studio. PhD thesis, Università Politecnica delle Marche, Ancona, Italy. [In Italian.] 
Azzurro, E. \& Andaloro, F., 2004. A new settled population of the lessepsian migrant Siganus luridus (Pisces: Siganidae) in Linosa Island-Sicily Strait. Fournal of the Marine Biological Association of the United Kingdom, 84, 819-821.

Bariche, M., 2006. Diet of the lessepsian fishes, Siganus rivulatus and $S$. luridus (Siganidae) in the eastern Mediterranean: a bibliographic analysis. Cybium, 30, 41-49.

Bariche, M., Letourner, Y. \& Harmelin-Vivien, M., 2004. Temporal fluctuations and settlement patterns of native and lessepsian herbivorous fishes on the Lebanese coast (eastern Mediterranean). Environmental Biology of Fishes, 70, 81-90.

Castriota, L., Scarabello, M.P., Finoia, M.G., Sinopoli, M. \& Andaloro, F., 2005. Food and feeding habits of pearly razorfish, Xyrichtys novacula (Linnaeus, 1758), in the southern Tyrrhenian Sea: variation by sex and size. Environmental Biology of Fishes, 72, 123-133.

Clarke, K.R. \& Warwick, R.M., 1994. Change in marine communities: an approach to statistical analysis and interpretation. Plymouth: Natural Environment Research Council.

Elton, C.S., 1958. The ecology of invasions by animals and plants. London: Methuen \& Co.

Ferry, L.A. \& Caillet, G.M., 1996. Sample size and data analysis: are we characterizing and comparing diet properly? In Feeding ecology and nutrition in fish (ed. D. MacKinlay and K. Shearer), pp. 71-80. San Francisco, USA: Symposium Proceedings, American Fisheries Society.

Golani, D., 1994. Niche separation between colonizing and indigenous goatfish (Mullidae) along the Mediterranean coast of Israel. Fournal of Fish Biology, 45, 503-513.

Golani, D., 1998. Impact of Red Sea fish migrants through the Suez Canal on the aquatic environment of the eastern Mediterranean. Bulletin. Yale University, School of Forestry and Environmental Studies, 103, 375-387.

Hanson, J.M. \& Leggett, W.C., 1986. Effect of competition between two freshwater fishes on prey consumption and abundance. Canadian Fournal of Fisheries and Aquatic Sciences, 43, 1363-1372.

Havelange, S., Lepoint, G., Dauby, P. \& Bouquegneau, J.M., 1997. Feeding of the sparid fish Sarpa salpa in a seagrass ecosystem: diet and carbon flux. PSZNI Marine Ecology, 18, 289-297.

Herbold, B. \& Moyle, O., 1986. Introduced species and vacant niches. American Naturalist, 125, 751-760.
Jennings, S., Reñones, O., Morales-Nin, B., Polunin, N.V.C., Moranta, J. \& Coll, J., 1997. Spatial variation in the ${ }^{15} \mathrm{~N}$ and ${ }^{13} \mathrm{C}$ stable isotope composition of plants, invertebrates and fishes on Mediterranean reefs: implications for the study of trophic pathways. Marine Ecology Progress Series, 146, 109-116.

Lundberg, B. \& Golani, D., 1995. Diet adaptations of lessepsian migrant rabbitfishes, Siganus luridus and S. rivulatus, to the algal resources of the Mediterranean coast of Israel. PSZNI Marine Ecology, 16, 73-89.

Lundberg, B., Ogorek, R., Galil, B.S. \& Goren, M., 2004. Dietary choices of siganids fish at Shiqmona reef, Israel. Israel fournal of Zoology, 50, 39-53.

Lundberg, B., Payatas, G. \& Argyrou, M., 1999. Notes on the diet of the lessepsian migrant herbivorous fishes, Siganus luridus and $S$. rivulatus, in Cyprus. Israel Fournal of Zoology, 45, 314

Petrakis, G. \& Papaconstantinou, C., 1990. Biology of Sparisoma cretense in the Dodecanese (Greece). Fournal of Applied Ichthyology, 6, 14-23.

Pinnegar, J.K. \& Polunin, N.V.C., 2000. Contributions of stableisotope data to elucidating food webs of Mediterranean rocky littoral fishes. Oecologia, 122, 399-409.

Serio, D., Alongi, G., Catra, M., Cormaci, M. \& Furnari, G., 2006. Changes in the benthic algal flora of Linosa island (Straits of Sicily, Mediterranean Sea). Botanica Marina, 49, 135-144.

Stergiou, K.I., 1988. Feeding habits of the lessepsian migrant Siganus luridus in the eastern Mediterranean, its new environment. Journal of Fish Biology, 33, 531-543.

Stergiou, K.I. \& Karpouzi, V.S., 2002. Feeding habits and trophic levels of Mediterranean fish. Reviewes in Fish Biology and Fisheries, 11, 217-254.

Verlaque, M., 1985. Note preliminaire sur le comportement alimentaire de Sarpa salpa (L.) (Sparidae) en Méditerranée. Rapport du Commission Internationale pour l'Exploration Scientifique de la Mer Méditeranée, 29, 193-196.

Vizzini, S., Sara, G., Michener, R.H. \& Mazzola, A., 2002. The role and contribution of the seagrass Posidonia oceanica (L.) Delile organic matter for secondary consumers as revealed by carbon and nitrogen stable isotope analysis. Acta Oecologica, 23, 277285.

Submitted 3 November 2006. Accepted 9 July 2007. 